\title{
The Effects of Human Capital Development on Organizational Performance
}

\author{
Dr. Cross Ogohi Daniel \\ Departments of Public Administration and Banking and Finance, \\ Nile University of Nigeria, \\ Abuja, Nigeria
}

\begin{abstract}
the aim of this research work is to highpoint all the effects of human capital development on organisational performance in Trust fund Pension Limited. Modern business nature is in the state of disorder, where competition is very high. Organizations that neglect change may be required to change from existence to nonexistence, therefore survival is the solution. To live, companies must uncover all available capital that can bring about competitive advantage. To create a competitive advantage, it is essential that firms truly influence on the workforce as a competitive weapon. Precisely, the study aimed to carry out the following objectives: to establish the relationship between Human capital management and organizational performance, to highlight the needs for human capital development for improved organizational performance. The study had a population size of 152, out of which a sample size of 110 was realized using Taro Yamane formula at 5\% error to tolerance and $95 \%$ level of confidence. Instrument used for data collection was primarily questionnaire. The total numbers of 110 copies of the questionnaire were distributed while 80 copies were returned. The descriptive research design was adopted for the study. Two hypotheses were tested using Pearson's moment correlation coefficient. The findings suggest that there was significant relationship between human capital management and organisational performance. The necessity for human capital development include teaching the skills and knowledge requires in new staff, upgrading the skills and knowledge of old employees, meeting the challenges of technological innovation acquiring the skills required in the competitive market and enhancing human capital resourcefulness. The study recommends that Human resource manage should ensure that proper identification, determination and assessment of human capital needs in the organization
\end{abstract}

Keywords - Human Capital Development, Training, Organization and Performance

\section{Introduction}

Human Capital can be said to be specifically within an economic setting as a manufacturing factor, and as an economic term used to describe the skills and knowledge that individuals attracts upon to generate outputs of value, such as innovation and productivity in job performance. It is no exaggeration in the assertion that the most significant resource of any organization is often said to be its people. People, knowledge and skills are known as human capital (HC), Human Capital is the central of intellectual capital that energies business performance.

[1] stated that People are the organizations greatest tool, providing the intellectual capital that drives differentiation and enhance value. Of course, an organization is nothing but inter-related groups of people whose activities are planned and coordinated to meet organizational objectives. An organization that is to manufacture goods and services has a good chance to survive and prosper if it consists of the right people. Organizations encounter several obstacles in meeting their goals and in a similar way, all employees report some difficulties in their efforts to be productive and efficient in their jobs, and to feel satisfied in their work-lives. The challenge to human resources 
management is to minimize these obstacles and problems.

Human capital is made up of imperceptible that workers make available for their employers. Human capital can also be well defined as the knowledge, skills, aptitudes and other learned traits adding to production. Skills signify individual abilities adding to production as a reason in the production function. There are two main components of human capital with strong complementarity; early ability and skills learned through formal education or training on the job. Human capital is different from other assets because it generates market proceeds only in proportion to the workers supply of labor.

Today, the business setting is very dynamic and undergoes a rapid change as a result of technological advancement, increased awareness and changing request of customers and the business environment generally. Business organizations, works in a difficult and competitive market characterized by advanced changes. As an outcome, human capital must to be kept abreast with the continuous changes in the business environment.

\section{Statement Of The Problem}

The productivity of workers is falling resulting to low performance of the organization. This is because most firms fail to send their employees on training due to lack of funds that is involved in embarking on employees training. Also most firms believe that workers are dubious in nature, after returning from training desert their firms to join other firms. For instance most Nigerian organization do not give their employee effective and efficient training, considering the cost implication of sending employees on quality training which result into low productivity.

Nevertheless, the issues of human capital development are not taken seriously by any organizations, this is because of the failure to acknowledge the fact that business setting has become very active and as such only those organizations with the right informational need in the business times can succeed with the right technological manpower to succeed in modern times. Failure to take training and development especially in modern organization will lead to stifling growth, lack of productivity and inability to compete favorably in the industry. Pertinent to the above the study seeks to investigate the effect of human capital development on organizational performance.

\section{Objectives Of The Study}

Given the statement of the problem above, this study aims to achieve the following objectives.

i. To establish the relationship between Human capital management and organizational performance

ii. To highlight the needs for human capital development for improved organizational performance.

\section{Research Hypotheses}

The following alternate hypotheses were formulated and will be tested in their null form.

H1: There is significant relationship between human capital and Organizational performance

H2: Human capital development needs does positively affects organizational performance

\section{Literature Review}

\subsection{Conceptual Framework}

[2] mentions "human capital as human resources. $\mathrm{He}$ also said that human capital is of two dimensions; first it is the financial, physical capital which he said to be the tangible assets. The second is the knowledgeable capital which he called the intangible assets. He went on to say that managing people is same as managing other physical assets". He supposes that organizations generate worth through the intangible assets or the intelligence in the employee. He also noted that human capital is the stash of knowledge, habits, social and personality attributes which consist of the creativities encircled in the capability to perform labor so as to produce more economic products or values. Human capital development according to [3] is said to be "about training and the development of these potential capabilities of the human capital or the people". They discoursed that human capital development is very crucial in order to have the maximum utilization of the manpower for the benefit and advantage of both the employees and the organization.

Human resource development or human capitals changes the human capital inputs into outputs. They said that "the inputs are the people, the individuals, and the groups in the society or organizations. The transformation procedure or the development processes are the managerial subsystems of 
acquiring, developing, allocating, conserving, utilizing, improving and motivating the people or the employees". They also viewed that "human resource development is done through education, training and development to improve the intellectual, skills and the attitudes of individuals and groups in an organization". It also consists of factors like personal dignity and status, team work and group dynamics. [4] gives their own opinions that employee performance as equal to job and income security, workplace health and safety.

At this particular stage it is the measurement of the result of the training. Employee performance according to a system is consisting of three main elements organized in a linear sequence: Inputs, which include employee knowledge, skills and competencies, as well as other tangible and intangible resources. The study evaluates that the employee provides work inputs in the form of knowledge, skills, abilities and attitudes. [5] are of the opinion that "employee performance is capability based, rather than personality based. Organizations are however encouraged to identify the state of development of their present performance management practices". To map out their aspirations for changing this procedure of managing employee performance and also to think about the problems they face along the way. From the studies so far, it is noteworthy for organizations to optimize employee performance.

The organization according to [6] should be organized to do this. "The organization needs to be responsive to the business context and the methods of attending to customers and their expectations. The organization should strike a balance between the characteristics needs of business they are in and what helps flourish the core traits of the employees to give customers' needs best". This study went further to analyze this in the context of: Technology starts up, i.e. high pointing changes and that employees are expected to have different skills and highly responsive.

\subsection{Determination of Human Capital Development Needs in Organizations.}

The training and development needs of any organization falls under two categories both of which are inter dependent. These are; Organizational training and Development Needs and Individual Training Needs

\section{i. Organization Training and Development Needs}

According to [7] "training and development should not be commended for their own sake. They must be engine to the objectives of the organization. No organization can plan out a realistic training and development programmes unless a thorough identification of the present human capital positions has been made and the organization's future map out plans and the types of human capital expected to have been decided upon".

It is therefore significant to know what the current skills are and based on the main objectives of the organization, what training is needed to meet the growth of the necessary skills for the accomplishment of the organization's objectives. [7] advances the following relevant questions;

a. Present position

i. What human capital do they need?

ii. What training have they had?

iii. What are the shortages or what skills are they lacking?

b. Based on organization's objectives

i. Who is required to be trained?

ii. What categories of employees or staff need special training programmes?

iii. How many of each category needs to be trained?

iv. How much time is available for the training?

\section{ii. Individual Training Needs}

As in the case maybe of the Pension fund administrator's needs, certain primary questions have to be asked with regard to the training needs of individual staff. These are;

i. What does the staff have to do?

ii. What particular skills does he need in order to do the job effectively?

iii. What skill has the got?

iv. What skills must be acquired to be able to do the job?

In order to know what skills and requirements the job needs, it will be advised to do a job research and job description bringing out clearly the various duties and responsibilities involved in the job [8]. 


\subsection{Human Capital Development and Firm Performance}

Human capital draws attention mainly on two (2) components which are individuals and organizations. These concepts have further been described by [9] that human capital has four basic attributes:

1. flexibility and adaptability

2. enhancement of individual

3. the development of organizational competencies and

4. Individual employability.

It demonstrates that these attributes in turn generates values to individual and organizational outcomes. There are various findings that incorporate human capital with advanced performance and sustainable competitive advantage [10]; and enhanced organizational retention [11]. Hence, all this debates fundamentally emphasize on individual and organizational performance.

From the individual level, [12] pointed out that "the importance of human capital depends on the degree to which it subsidizes to the creation of a competitive advantage. From an economic point of view, transactions-costs designate that firm gains a competitive advantage when they own firm-particular resources that cannot be copied or rivaled. Thus, as the uniqueness of human capital increases, firm have inducements to invest resources into its management and the purpose to reduce risks and get the most out of productive potentials. Hence, individuals need to enhance their competency skills in order to be competitive in their organizations".

"The human capital theory has undergone a rapid development. Within its development, attention has been paid to training related aspects. This is much related to the individual perspective. Human capital investment is any activity which improves the quality (productivity) of the worker. Therefore, training is an important component of human capital investment. This refers to the knowledge and training required and undergone by a person that increases his or her capabilities in performing activities of economic values.

In addition, [13] has noted that "human capital as a source not only to motivate workers and boost up their commitment but also to create expenditure in $\mathrm{R}$ $\& \mathrm{D}$ and eventually pave a way for the generation of new knowledge for the economy and society in general. Also, for small businesses it is a valuable asset, which is positively associated with business performance. Finally, investment in training is a desirable form both a personal and social perspective".

From the organizational point of view, human capital plays a very crucial role in the strategic planning on how to produce competitive advantages. Following [14] it is stated that "a firm's human capital has two dimensions which are value and uniqueness. Firm indicates that resources are valuable when they allow improving effectiveness, capitalizing on opportunities and neutralizing threats. In the context of effective management, value focuses on increasing profits in comparison with the associated costs. In this sense, firm's human capital can add value if it contributes to lower costs, provide increased performances".

\section{Methodology}

This research therefore covers the selected Trustfund Pension Limited Headquarters in Abuja. Secondary data were gotten through books, journals, and internet. Empirical reviews of other scholars were consulted. A simple size of 110 was obtained from the population of 152 at $5 \%$ error tolerance and $95 \%$ degree of freedom using Yamane's statistical formula 110(100\%) of the questionnaires distributed $80(73 \%)$ were returned and $30(27 \%)$ were not answered and returned. The questionnaire was designed in Likert scale format. The researchers conducted a pre-test on the questionnaire to guarantee the validity of the instrument. Pearson product moment correlation coefficient was used to test the hypotheses.

\section{Results}

The two hypotheses were tested with various test statistics aided by computer applied Statistical Package for Social Sciences (SPSS: 21.00s version) of Microsoft environment. Specifically, Pearson product moment correlation coefficient and simple linear regression were used to test the hypotheses.

\section{Test of Hypothesis one}

$\mathrm{H}_{1}$ : There is no significant relationship between human capital and Organizational performance

$\mathrm{H}_{0}$ : There is a significant relationship between human capital and Organizational performance 
Table No 1: Table of correlation between human capital and organizational performance

Correlations

\begin{tabular}{|l|l|c|c|}
\hline & & Human capital & $\begin{array}{c}\text { organisational } \\
\text { performance }\end{array}$ \\
\hline Human Capital & $\begin{array}{l}\text { Pearson } \\
\text { Correlation } \\
\text { Sig. (2-tailed) } \\
\mathrm{N}\end{array}$ & 200 & $\begin{array}{c}.536^{* *} \\
.000\end{array}$ \\
\hline $\begin{array}{l}\text { Organisational } \\
\text { performance }\end{array}$ & $\begin{array}{l}\text { Pearson } \\
\text { Correlation } \\
\text { Sig. (2-tailed) } \\
\mathrm{N}\end{array}$ & $.536^{* *}$ & 80 \\
\hline
\end{tabular}

**. Correlation is significant at the 0.01 level (2tailed).

According to above calculations it is observed that amount of correlation coefficient between organizational performance and human capital is equal to 53.6 per cent and considering that a significant level is less than 5\%. Then we can say that there is a positive relationship between human capital and organizational performance.

Table No 2: Model Summary

\begin{tabular}{|l|l|l|l|l|}
\hline Model & R & R Square & $\begin{array}{l}\text { Adjusted } \\
\text { R Square }\end{array}$ & $\begin{array}{l}\text { Std. Error of } \\
\text { the Estimate }\end{array}$ \\
\hline 1 & $.965^{\mathrm{a}}$ & .716 & .586 & 3.79952 \\
\hline
\end{tabular}

a. Predictors: (Constant), human capital

Regression coefficient of $\mathrm{R}=.965$ or $96.5 \%$ indicate that relationship exist between independent variables and dependent variable. The coefficient of determination $\mathrm{R}^{2}=0.716$ which show that $71.6 \%$ of variation in organizational performance is explained by human capital development. The adjusted Rsquare in the table shows that the dependent variable, (level of performance) is affected by $58.6 \%$ by independent variable.

Table No 3: Coefficients ${ }^{\mathrm{a}}$

\begin{tabular}{|l|l|l|l|l|l|}
\hline Model & \multicolumn{2}{|l|}{$\begin{array}{l}\text { Unstandardized } \\
\text { Coefficients }\end{array}$} & $\begin{array}{l}\text { Standardized } \\
\text { Coefficients }\end{array}$ & $\mathrm{t}$ & \multirow{2}{*}{ Sig. } \\
\cline { 2 - 5 } & $\mathrm{B}$ & $\begin{array}{l}\text { Std. } \\
\text { Error }\end{array}$ & Beta & & \\
\hline $\begin{array}{l}\text { (Constant) } \\
\text { human capital }\end{array}$ & 12.310 & .901 & & 13.656 & .002 \\
& 1.056 & .085 & .536 & .000 \\
& & & & 12.426 & \\
\hline
\end{tabular}

a. Dependent Variable: organizational performance The coefficient of determination for human capital is positive (1.056) and is highly significant (0.001) in ensuring organizational performance. The p-value of 0.000 is less than the t-statistic value of 12.426 and the standard error value of 0.085 . Therefore, the null hypothesis is rejected and alternate hypothesis is accepted there is a significant relationship between human capital and Organizational performance

\section{Hypothesis two}

$\mathrm{H}_{0}$ : Human capital development needs positively affects organizational performance

$\mathrm{H}_{2}$ : Human capital development needs does positively affects organizational performance

Table No 4: Table of correlation between human capital needs and organizational performance

\section{Correlations}

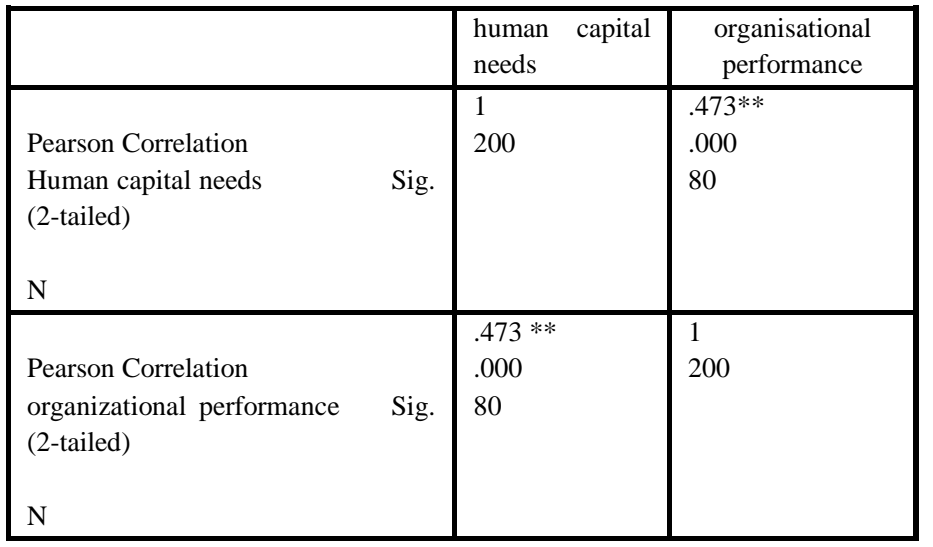

**. Correlation is significant at the 0.01 level (2tailed).

According to above calculations is observed that amount of correlation coefficient between human capital needs and improving organization performance is equal to 47.3 per cent and considering that a significant level is less than 5\%. Then we can say that there is a positive relationship between human capitals needs and improving the organization performance. This implies that one percent increase in human capital needs will lead to $47.3 \%$ increase in improving the organizational performance

\section{Table No 5: Regression analysis test of human capital needs and organizational performance Model Summary}

\begin{tabular}{|l|l|l|l|l|}
\hline Model & $\mathrm{R}$ & R Square & $\begin{array}{l}\text { Adjusted } \\
\text { R Square }\end{array}$ & $\begin{array}{l}\text { Std. Error of } \\
\text { the Estimate }\end{array}$ \\
\hline 1 & $.773^{\text {a }}$ & .624 & .722 & 3.96426 \\
\hline
\end{tabular}

a. Predictors: (Constant), human capital needs 
Regression coefficient of $\mathrm{R}=.773$ or $77.3 \%$ indicate that relationship exist between independent variables and dependent variable. The coefficient of determination $\mathrm{R}^{2}=0.624$ which show that $62.4 \%$ of variation in improving the organizational performance is explained by human capital needs. The adjusted R-square in the table shows that the dependent variable is affected by $72.2 \%$ by independent variable. It shows that there is a positive relationship between Human capital development and organizational performance.

Table No 6: Coefficients ${ }^{\mathrm{a}}$

\begin{tabular}{|c|c|c|c|c|c|}
\hline \multirow[t]{2}{*}{ Model } & \multicolumn{2}{|c|}{$\begin{array}{l}\text { Unstandardized } \\
\text { Coefficients }\end{array}$} & $\begin{array}{l}\text { Standardized } \\
\text { Coefficients }\end{array}$ & \multirow[t]{2}{*}{$\mathrm{t}$} & \multirow[t]{2}{*}{ Sig. } \\
\hline & B & $\begin{array}{l}\text { Std. } \\
\text { Error }\end{array}$ & Beta & & \\
\hline $\begin{array}{l}1 \text { (Constant) } \\
\text { human capital } \\
\text { needs }\end{array}$ & $\begin{array}{l}15.036 \\
1.319\end{array}$ & $\begin{array}{l}.806 \\
.125\end{array}$ & .473 & $\begin{array}{c}18.644 \\
10.520\end{array}$ & $\begin{array}{l}.000 \\
.000\end{array}$ \\
\hline
\end{tabular}

a. Dependent Variable: organizational performance The coefficient of determination for human capital needs is positive (1.319) and is highly significant (0.000) in organizational performance. The $p$-value of 0.000 is less than the $t$-statistic value of 10.520 and the standard error value of 0.125 . This implies that a unit increase in human capital needs to 1.319 increases in organizational performance. Therefore, the null hypothesis is rejected and alternate hypothesis is accepted concluding that Human capital development needs positively affects organizational performance

\section{Conclusion}

The need for human capital development for sustainability and growth rises essentially from the detail that there are continuous changes in the business settings. The contenders of these changes makes it imperative for human capital to be continuously trained and retrained in order to meet up with such difficulties. This is the only way banks can safeguard sustainability and growth in their competitive marketing environment.

Efficient human capital development ensures improved organizational performance through heightened productivity, efficient provision of services, effective customer relations management, improved competitiveness and acquiring skills in ICT. Thus, efficient human capital development enhances productivity to a great extent and impacts single handedly on sustainability and growth of the organization.

\section{Recommendations}

In the time of constant changes in an organization with its problems to sustainability and growth, the following recommendations are made;

i. The Human resource managers should ensure that proper diagnosis, determination and assessment of human capital needs in the organization. This will guarantee that the right number and categories of staff are selected for the training and development programs.

ii. There should be constant research on developments in the organizational environment that requires training and upgrading and improving the skills of employees. Thus will allow the right training and development programs to be mapped out and implemented so as to keep the employees abreast with the developments.

iii. The whole programs should be carefully and thoroughly designed. This includes making sure that the syllabus contains what is required of the employees to know, to have competent trainers, adequate and necessary training facilities and regularity of the programs.

iv. There should be adequate and effective system of rewarding successful trainees. This includes promotion, advancement and status enhancement as well as increased responsibility. These will serve as encouragement for effective participation in staff training and development programs.

v. Finally, the programs should be continuously carried out to enhance productivity of staff, which is vital for sustainability and growth.

\section{References}

[1] [1] J Choudhury, Mr. S. C. Nayak (2011) "An Empirical Investigation of Impact of Acquisitions HR Configuration on Human Capital Development". Global Journal of Management And Business Research Volume 11 Issue 2. International 
Research Journal Publisher: Global Journals Inc. (USA

[2] [2] Armstrong, M. (2006). "Strategic Human Resource Management: A Handbook of Human Resource Management Practice", 10th ed. London: Kogan Page.

[3] [3] Qureshi M. T. and Ramay I. M. (2006). "Impact of Human Resource Management Practices on Organizational Performance in Pakistan", Muhammad Ali Jinnah University, Islamabad.

[4] [4] Tang, T.L., Chiu, R.K., and Luk, V.W. (2002). "Retaining and Motivating Employees: Compensation Preferences in Hong Kong and China". Personal Review, 31(4), 402-431.

[5] [5] Elizabeth Boye, Kuranchie-Mensah1, Kwesi Amponsah-Tawiah (2013) "Employee Motivation and Work Performance: A Comparative Study of Mining Companies in Ghana" Journal of Industrial Engineering and Management, JIEM, 2016 - 9(2): 255-309

[6] [6] Hilson, G., \& Banchirigah, S. M. (2009). "Are alternative livelihood projects alleviating poverty in mining communities? Experiences from Ghana". Journal of Development Studies, 45, 172 196

[7] [7] Ighodaro, E (2005) "Human Capital Development". Benin City: Ethiope Publishers

[8] Adewale, A (2005) Managing Human organizations. Ibadan: spectrum 73 (JulyAugust), pp.118-128.

[9] Garavan, T. N., Morley, M., Gunnigle, P. and Collins, E. (2001). "Human capital accumulation: The role of human resource development". Journal of European Industrial Training, 25 (2-4), pp. 48-68.

[10] Nordhaug, O. (1993). "Human capital in organizations": Competency, training and learning. Oslo: Scandinavian University Press.

[11] Schultz, T. W. (1961) "Investment in Human Capital". The American
Economic Review, Vol. 51 No 1/1961, pp. 1-17. Available on: http://www.jstor.org/pss/1818907

[12] Collis, David and Cynthia A. Montgomery (1995), "Competing on Resources: Strategy in the 1990s," Harvard Business Review,

[13] Odhong E. A. and Were S. (2013). "Human Capital Management as a Tool for Value Creation", in Proceedings of First SHRD Annual Research Conference, 12th and 13th September, Nairobi. Jomo Kenyatta University of Agriculture and Technology main campus.

[14] Snell, S. A., Lepak, D. P., Dean Jr., J. W. and Youndt, M. A. (2000a). "Selection and training for integrated manufacturing: The moderating effects of job characteristics". Journal of Management Studies, 37 (3), pp. 445466.

\section{Author's Profile}

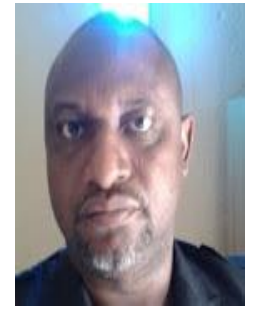

Cross Ogohi Daniel is a Head of Department of Public Administration/ Banking \& Finance at Nile University of Nigeria, Abuja. He is a seasoned Human Resources Manager with over 15 years of experience in human resource management. He has had the opportunity to transform the mundane activities of human resources for various organizations across the globe. He holds an MBA degree in management and a $\mathrm{PhD}$ degree in management from the prestigious university of Nigeria, Nsukka. His research interests are primarily in the areas of Human Resource Management, Quantitative Techniques, Management Theories, Entrepreneurship Development, Strategic Management, Feasibility Study and Market Research and Organizational Justice. He is widely published in reputable national and international journals. 